\title{
「空気圧入法」と「水分法」による 砂の間隙径分布
}

\author{
宇野尚雄 $^{1} \cdot$ 神谷浩二 $^{2} \cdot$ 田中宏路 ${ }^{3}$ \\ 1フェロー 工博 岐阜大学教授 工学部土木工学科( テ501-1193 岐阜市柳戸 1-1) \\ ${ }^{2}$ 正会員 工修 岐阜大学助手 工学部土木工学科(同上) \\ ${ }^{3}$ (株) 大林組 東北支店 (T 980-0011 仙台市青葉区上杉 1-6-11)
}

\begin{abstract}
土の間隙構造を表現する重要な要因である間隙径分布の計測手法として，筆者らが提案した「空気圧入 法」は，複雑な間隙構造を毛管の集合体とみなす毛管モデルの仮定に基づいている．本論文では，この圧 入法による間隙径分布と水分特性曲線から推定する「水分法」によるものを対比した. その結果，水分法 による間隙径分布に較べて, 圧入法によるものは粒度に関係なく分布範囲が狭く均等な分布型となること， 平均間隙径は 9 割程度の大きさとなることが判明した. そして，手法の原理的相違性の観点から両手法に よる間隙径分布について考察し，関倸付けを試みるとともに，圧入法における空気通過最小圧は，水分特 性曲線から得られる空気侵入值の 6 割程度の大きさであることを認めた.
\end{abstract}

Key Words : void diameter, capillary model, air intrusion method, moisture characteristic curve, sand

1. はじめに

土の複雑な間隙構造を表現する重要な要因である 間隙径分布を計測する手法として, 筆者らは, 「空 気圧入法」(以下，圧入法と呼ぶ)を提案した ${ }^{1)}$. こ れは, 飽和土試料への空気圧入により, その圧入圧 力と空気透過量の関係から間隙径分布を求める方法 であり, 簡便なものである. 一方, 間隙構造と水分 特性曲線を関連づけて, 水分特性曲線から間䏚径分 布を推定する手法(以下，水分法と呼ぶ)がある2)，3). これは, Childs $ら^{4)}$, Baver ${ }^{5)}$, Marshall ${ }^{6)}$, 等によ って述べられているけれども, 計測した間隙径分布 との対比は十分に検討されていない.

本論文は, 砂質土に関して, 圧入法により計測す る間隙径分布と水分法により推定する分布を対比し, 間隙構造の計測・推定及び表現法に関する指針を得 ることを目的とするものである.いずれの手法も「間 隙部分はまっすぐに連続した種々の直径の円形毛管 の集合体である」とする一次元的な毛管モデルの仮 定に基づく．しかし，後述するように，圧入法によ る間隙径分布は均等になり易いのに対して, 水分法 のそれはより広い範囲の間隙径分布になるため, 間 隙径の変化する複雑な間隙構造の三次元的影響を受
けていると想像され，両者の分布差の意味を考察す ることにより, 間隙構造の理解を深められ, 地盤注 入材の砂質土の間隙への侵入 ・滞留 • 付着の機構解 明 (本論文では議論しない) 等に繫がると期待される.

本文では, 最初に水分特性曲線から間隙径分布を 推定する手法を整理した後, 両手法による間隙径分 布を対比した結果を示す. そして, 両手法の原理的 な違いを対比しながら, 圧入法の間隙径分布や両手 法の間隙径分布の関係について考察し，また，水分 特性曲線から得られる Brooks らの空気侵入值に対 して ${ }^{7)}$, 圧入法の空気通過最小圧を比較する.

\section{2. 水分法による間隚径分布}

\section{(1) 推定方法}

図ー1 のように，任意の高さの毛管モデル中を水 が毛管上昇しているとき，その毛管束の含水状態は 土の水分特性曲線に等しいとして, 求められる毛管 束の管径分布を土の間隙径分布とみなす方法である. 参考文献 2)，3）に記載されている手法を整理する と以下のようである.

図ー1 の毛管束を任意の高さで切断したとき, 直 径が $d_{m}(\mathrm{~mm})$ から $d_{m}+d\left(d_{m}\right)$ の間にある毛管が占める 




図-1 毛管束の含水状態

断面積 $d A_{v}\left(\mathrm{~cm}^{2}\right)$ の，毛管束 (試料層) の全断面積 $A\left(\mathrm{~cm}^{2}\right)$ に対する割合を次のように表す.

$$
\frac{d A_{v}}{A}=f\left(d_{m}\right) d\left(d_{m}\right)
$$

ここに, $f\left(d_{m}\right)$ : 毛管径の分布密度関数

これは, 毛管束のある切断面においてある大きさの 毛管が存在する確率を表している. そして，その毛 管束の面積率, 即ち, 間隙率 $n$ は次式で与えられる.

$$
n=\int_{A_{v, \text { min }}}^{A_{v, \text { max }}} \frac{d A_{v}}{A}=\int_{d_{m, \text { min }}}^{d_{m \text { max }}} f\left(d_{m}\right) d\left(d_{m}\right)
$$

ここに, $A_{v, \text { max }}$ : 最大毛管径 $d_{m, \max }(\mathrm{mm})$ を有する毛 管部分の断面積 $\left(\mathrm{cm}^{2}\right)$

$A_{v, \text { min }}$ : 最小毛管径 $d_{m, \text { min }}($ (mw) を有する毛管 部分の断面積 $\left(\mathrm{cm}^{2}\right)$

一方, 毛管束の任意の高さの切断面において, 水で 満たされている毛管部分の面積率, 即ち, 体積含水 率 $\theta$ は, 式(2)に基づいて, 次式によって表される.

$$
\theta=\int_{d_{m, \text { min }}}^{d_{m, i}} f\left(d_{m}\right) d\left(d_{m}\right), \quad f\left(d_{m}\right)=\frac{d \theta}{d\left(d_{m}\right)}
$$

ここに, $d_{m, i}:$ 水で満たされている毛管部分の内 での最大の毛管径 $(\mathrm{mm})$

ところで, 毛管径 $d_{m}(\mathrm{~mm})$ は, 毛管上昇高さ, 即ち, サクション $h_{p}(\mathrm{~cm})$ から次式により算出される.

$$
d_{m}=\frac{4 \sigma}{\rho_{w} g h_{p}} \cdot 10^{4}
$$

ここに, $\sigma$ : 水の表面張力 $(\mathrm{N} / \mathrm{m})$ (水温 $T_{w}=15^{\circ} \mathrm{C}$ の

$$
\text { とき } \left.\sigma=73.48 \times 10^{-3}(\mathrm{~N} / \mathrm{m})\right)
$$

$\rho_{w}:$ 水の密度 $\left(\mathrm{g} / \mathrm{cm}^{3}\right)$

$g:$ 重力加速度 $\left(\mathrm{cm} / \mathrm{s}^{2}\right)$

式(4)を微分して,

$$
d\left(d_{m}\right)=-\frac{4 \sigma}{\rho_{w} g h_{p}{ }^{2}} \cdot 10^{4} d h_{p}=-\frac{d_{m}}{h_{p}} d h_{p}
$$

更に, 式(5)に式(4)を代入すると次式が得られる.

$$
\frac{d h_{p}}{d\left(d_{m}\right)}=-\frac{h_{p}}{d_{m}}=-\frac{4 \sigma}{\rho_{w} g d_{m}{ }^{2}} \cdot 10^{4}
$$

そして，式(3)，(6)より，f(d $\left.d_{m}\right)$ は次式で表される.

$$
f\left(d_{m}\right)=\frac{d h_{p}}{d\left(d_{m}\right)} \frac{d \theta}{d h_{p}}=-\frac{4 \sigma}{\rho_{w} g d_{m}{ }^{2}} \cdot 10^{4} \frac{d \theta}{d h_{p}}
$$

よって， $\theta \sim h_{p}$ (負圧を正とする)関係で表す土の 水分特性曲線が毛管束のそれと等しいとすれば, 式 (4)により間隙径 $d_{m}$ が, 式 (7)により間隙径の分布 密度関数 $f\left(d_{m}\right)$ がそれぞれ求められる。

次に, 本論文では, 間隙量を表す累積間隙体積百 分率 $V_{r}(\%)$ を次式により定義する.

$$
V_{r}=\frac{\int_{d_{m, \text { min }}}^{d_{m, i}} f\left(d_{m}\right) d\left(d_{m}\right)}{\int_{d_{m, \text { min }}}^{d_{m, \text { max }}} f\left(d_{m}\right) d\left(d_{m}\right)} \cdot 10^{2}
$$

これは，式(2)，(3)より次のように書き換えられる.

$$
V_{r}=\frac{\theta}{n} \cdot 10^{2}=S_{r}
$$

ここに, $S_{r}:$ 飽和度 $(\%)$

即ち, $\theta \sim h_{p}$ 関係で表す水分特性曲線を $S_{r} \sim h_{p}$ 関係 で表現し直し， $h_{p}$ を式(4)により $d_{m}$ に換算すれば， $d_{m} \sim V_{r}\left(=S_{r}\right)$ 関係で間隙径分布を表すことができる.

\section{(2) 水分特性曲線}

図ー2 は, 吸引法の一つであるサクションプレー 卜法 (試料層住直径 $50 \mathrm{~mm}$, 高さ $L=20 \mathrm{~mm}$ の円柱体) により計測した排水過程，浸透過程での水分特性曲 線をそれぞれ示したものである8). 図中の一点鎖線, 二点鎖線及び破線は, 水分特性曲線の全体像を調心 るために, 次の van Genuchten の水分特性曲線の推 定式 :

$$
S_{e}=\frac{\theta-\theta_{r}}{\theta_{s}-\theta_{r}} \cdot 10^{2}=\frac{1}{\left\{1+\left(\alpha h_{p}\right)^{n^{*}}\right\}^{m}} \cdot 10^{2}
$$

$$
\text { 但し, } m=1-1 / n^{*}
$$

ここに， $S_{e}$ : 有効飽和度 $(\%)$

$$
\begin{aligned}
& \theta_{r}: \text { 残留体積含水率 } \\
& \theta_{s}: \text { 飽和体積含水率 } \\
& \alpha: \text { 土の種類で決まるパラメータ }(1 / \mathrm{cm}) \\
& n^{*}: \text { 土の種類で決まるパラメータ }
\end{aligned}
$$

により ${ }^{9)}, \theta_{r}=0, \theta_{s}=n$ と仮定して, 計測值に対 して最小二乗法により近似したものである。表ー1 には，各計測試料に関する $\alpha, n^{*}$ を示した。

\section{(3) 間隙径分布}

図ー2 のそれぞれを $90^{\circ}$ 左回転して，横軸のサク 

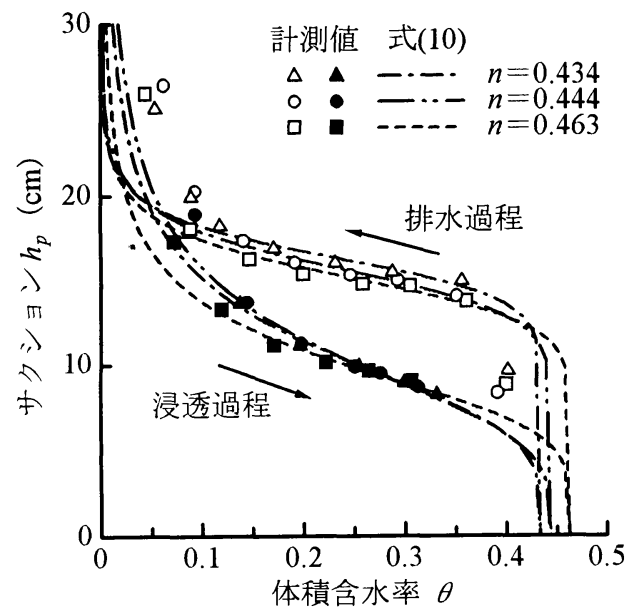

図-2(a) 水分特性曲線 (粗砂)

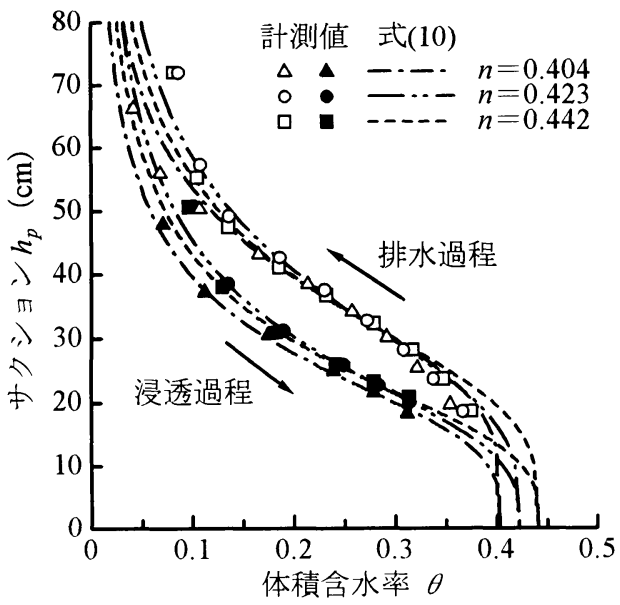

図-2(b) 水分特性曲線 (混合砂)

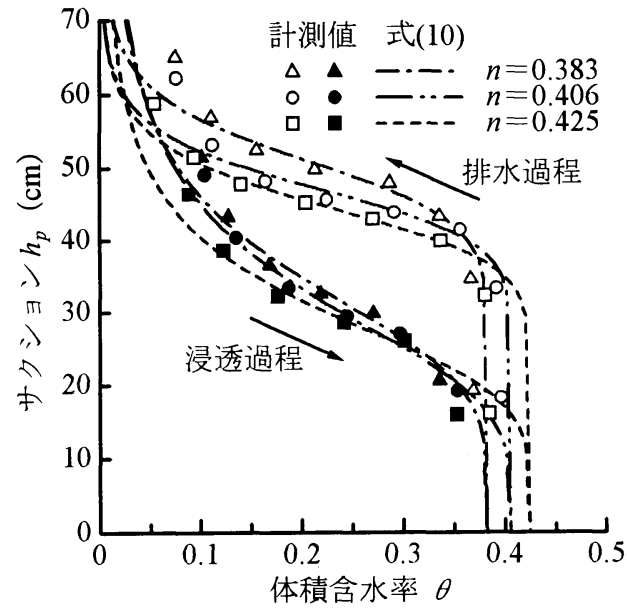

図-2(c) 水分特性曲線 (標準砂)
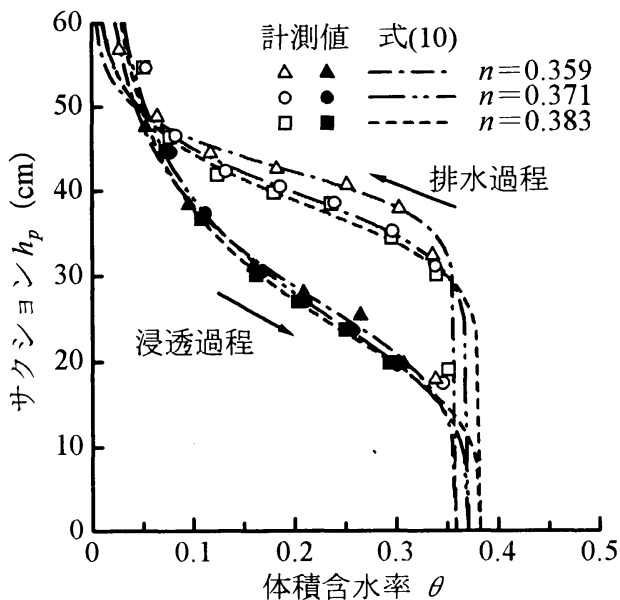

図一2(d) 水分特性曲線 (GB-AC(ガラスビーズ))

表ー1 van Genuchten 式(10)におけるパラメータ $\alpha, n^{*}$

\begin{tabular}{|c||c|c|c|r|}
\hline 試料名称 & 間隙率 $n$ & 過程 & \multicolumn{1}{|c|}{$\alpha$} & \multicolumn{1}{|c|}{$n^{*}$} \\
\hline \hline 粗砂 & \multirow{2}{*}{0.434} & 排水 & 0.0613 & 12.584 \\
& & 浸透 & 0.1012 & 4.159 \\
& \multirow{2}{*}{0.444} & 排水 & 0.0641 & 10.546 \\
& & 浸透 & 0.1040 & 3.806 \\
& \multirow{2}{*}{0.463} & 排水 & 0.0664 & 10.451 \\
& & 浸透 & 0.1056 & 4.812 \\
\hline 混合砂 & \multirow{2}{*}{0.404} & 排水 & 0.0281 & 4.078 \\
& & 浸透 & 0.0418 & 3.543 \\
& \multirow{2}{*}{0.423} & 排水 & 0.0296 & 3.431 \\
& & 浸透 & 0.0412 & 3.163 \\
& \multirow{2}{*}{0.442} & 排水 & 0.0304 & 3.643 \\
& & 浸透 & 0.0425 & 3.306 \\
\hline
\end{tabular}

\begin{tabular}{|c||c|c|c|r|}
\hline 試料名称 & 間隙率 $n$ & 過程 & $\alpha$ & \multicolumn{1}{|c|}{$n^{*}$} \\
\hline \hline 標淮砂 & 0.383 & 排水 & 0.0196 & 11.538 \\
& & 浸透 & 0.0305 & 4.489 \\
& \multirow{2}{*}{0.406} & 排水 & 0.0212 & 12.298 \\
& & 浸透 & 0.0335 & 4.083 \\
& \multirow{2}{*}{0.425} & 排水 & 0.0225 & 10.771 \\
& & 浸透 & 0.0349 & 4.805 \\
\hline $\mathrm{GB}-\mathrm{AC}$ & \multirow{2}{*}{0.359} & 排水 & 0.0235 & 13.631 \\
& \multirow{3}{*}{0.371} & 浸透 & 0.0356 & 4.548 \\
& & 排水 & 0.0251 & 9.666 \\
& \multirow{2}{*}{0.383} & 浸透 & 0.0381 & 3.914 \\
& & 排水 & 0.0260 & 8.885 \\
& 浸透 & 0.0402 & 3.868 \\
\hline
\end{tabular}

ション $h_{p}$ を式(4)により間隙径 $d_{m}$ に変換したものを 対数スケールで表示し, 縌軸の体積含水率 $\theta$ を式(9) により累積間隙体積百分率 $V_{r}$ に変換したのが図ー3 であり，粒度，均等係数 $U_{c}$, 次式 (11) で算出する平
均粒径 $D_{w}(\mathrm{~mm})^{10)}$, 及び後述の圧入法による間隙径 分布をそれぞれ併せて示した.

$$
D_{w}=1 / \sum\left(P_{i} / D_{i}\right)
$$






図一3（a）水分法と圧入法による間隙径分布の対比(粗砂)



図－3(b) 水分法と圧入法による間隙径分布の対比 (混合砂)

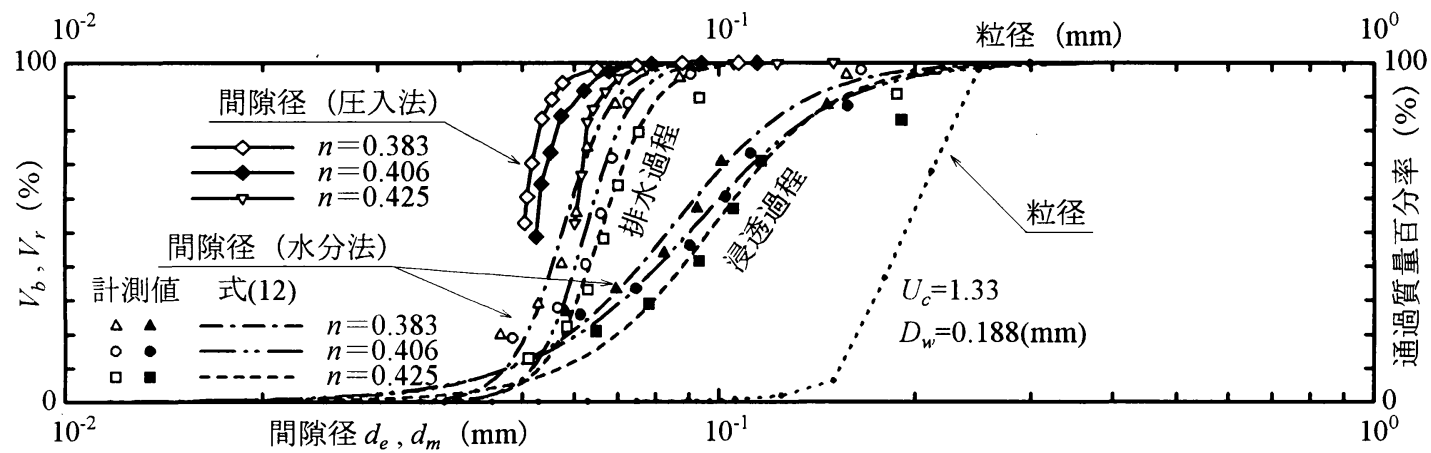

図－3(c) 水分法と圧入法による間隙径分布の対比(標準砂)

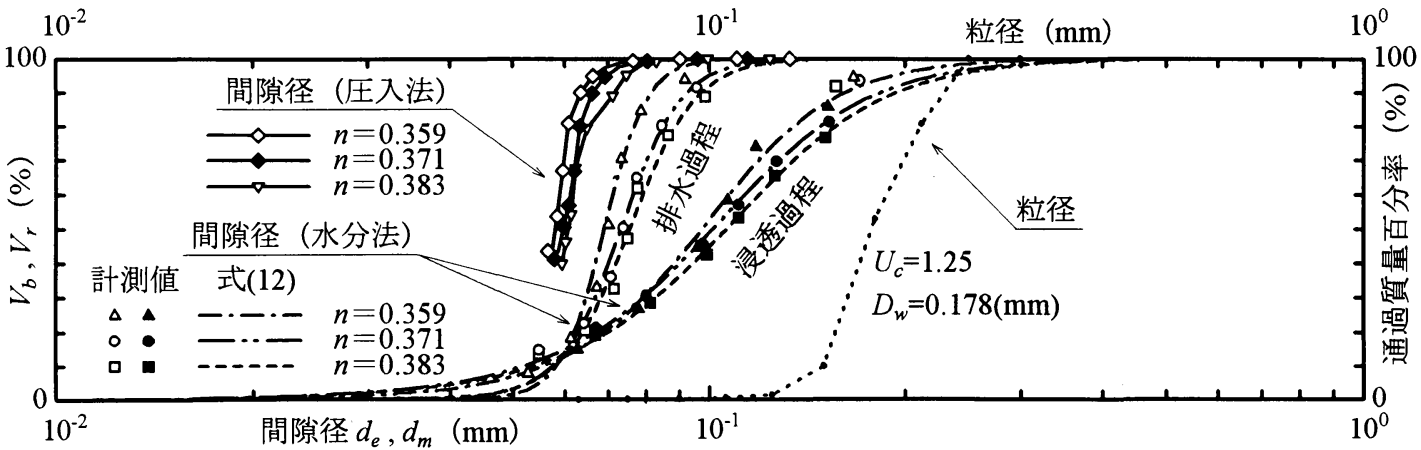

図ー3(d) 水分法と圧入法による間隙径分布の対比 (GB-AC) 
ここに, $P_{i}$ : ある粒径範囲の中間径 $D_{i}(\mathrm{~mm})$ を有す る試料の質量が全試料質量に対して 占める割合．本論では， $D_{i}$ は粒度試 験 (ふるい分け法)に用いたふるいの JIS 目開き $0.850,0.710,0.600,0.500$, $0.425,0.355,0.300,0.250,0.212$, $0.180,0.150,0.125,0.106,0.090$, $0.075,0.063,0.053,0.045,0.038$, 0.032 (単位は $\mathrm{mm}$ )の中間径とした.

図中の一点鎖線, 二点鎖線及び破線は間隙径分布の 全体像を調べるために，式(10)に式(4)を代入し， $\theta_{r}=0, \theta_{s}=n$ と仮定して式(9)の関係に基づいて書 き換えた次式を，表一1 の $\alpha, n^{*}$ 用いて，それぞ れ図示したものである。

$$
V_{r}=\frac{1}{\left\{1+\left(\alpha \frac{4 \sigma}{\rho_{w} g d_{m}} \cdot 10^{4}\right)^{n^{*}}\right\}^{m}} \cdot 10^{2}
$$

図一2 の排水と浸透過程での水分特性曲線のヒス テレシスのため，図ー3 のように同一の試料，間隙 率に対して $2 つ の$ 間隙径分布が得られる。しかしな がら, 後述の圧入法による間隙径分布との対比には, 圧入法によるものが空気圧入に伴う間隙水の排水過 程で得られるため，水分法の排水過程でのものを用 いるのが適切と考える. 以下に述べる水分法による 間隙径分布は，排水過程でのものである.

図－3によれば，水分法による間隙径分布は粒度 を粒径軸方向に平行移動したような分布型を示し， また, $U_{c}$ の増加に伴い分布範囲は広くなり，間隙率 の増加に伴い間隙径軸方向に平行移動して間隙径が 大きくなる傾向にそれぞれある.

一方，粒径に対する間隙径の大きさに関して，図 -4 は, 次式(13)で定義して算出する水分法による 平均間隙径 $d_{m}{ }^{*}(\mathrm{~mm})$ の平均粒径 $D_{w}$ に対する比を間隙 比 $e$ に対して示したものであるが(後述する $e$ と圧 入法による平均間隙径 $d_{e}^{*}(\mathrm{~mm})$ の $D_{w}$ に対する比の関 係も併記),$d_{m}^{*} / D_{w}=0.25 \sim 0.4$ の大きさである.

$$
\begin{aligned}
d_{m}{ }^{*}=4 \frac{V_{v}}{S} \cdot 10 & =4 \frac{\int_{A_{v, \text { min }}}^{A_{\mathrm{v} \text { max }}} d A_{v}}{\int_{A_{v, \text { min }}}^{A_{v, \text { max }}} \frac{d A_{v}}{\left\{\left(d_{m} / 10\right) / 4\right\}}} \cdot 10 \\
& =\frac{\int_{d_{m, \text { min }}}^{d_{m, \text { max }}} f\left(d_{m}\right) d\left(d_{m}\right)}{\int_{d_{m, \text { min }}}^{d_{m, \text { max }}} \frac{f\left(d_{m}\right)}{d_{m}} d\left(d_{m}\right)}
\end{aligned}
$$

ここに, $V_{v}$ : 評価された間隙部分の全体積 $\left(\mathrm{cm}^{3}\right)$

$S:$ 評価された間隙部分の全表面積 $\left(\mathrm{cm}^{2}\right)$ なお，各々の試料，間隙率での $d_{m}{ }^{*}$ は，図-3の水分

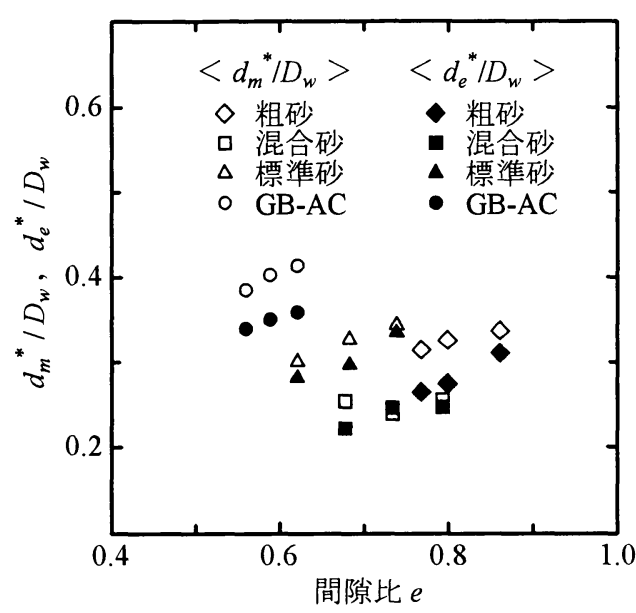

図-4 間隙比と平均間隙径 ·平均粒径との関係

法による間隙径分布にフィッティングさせたときの 式(12)による分布を用いて式(13)で算出している.

\section{3. 圧入法による間隚径分布}

\section{(1) 計測原理及び整理法 ${ }^{11}$}

蒸留水で飽和した試料層 (直径 $80 \mathrm{~mm}$, 高さ $L=30 \mathrm{~mm}$ の円柱体) の底面から空気圧力水頭 $h_{a}(\mathrm{~cm})$ を与える と，空気圧が $h_{a, m i n}(\mathrm{~cm})$ になるときに空気が鉛直上向 きに試料層中を流れ始める ${ }^{1)}$. 更に，空気圧を徐々 に増加すると, $h_{a}$ と飽和試料層を通過する空気の流 量 $Q_{a}\left(\mathrm{~cm}^{3} / \mathrm{s}\right)$ との関係は, 図ー5 の(2)のように, 空 気圧が $h_{a, \text { min }}$ から $h_{a, \text { max }}(\mathrm{cm})$ の範囲では曲線関係とな $\eta, h_{a, \max }$ より大きくなるときは乾燥試料の直線関係 (1)を $h_{a}$ 軸方向に平行移動した関係と一致する.

関係(2)において，ある空気圧 $h_{a, i}$ のときの固有透 過度 $k_{i}\left(\mathrm{~cm}^{2}\right)$, 透気係数 $k_{a, i}(\mathrm{~cm} / \mathrm{s})$ は, 次式によって それぞれ表される。

$$
k_{i}=\frac{\eta_{a} L}{\rho_{w} g A} \frac{Q_{a, i}}{h_{a, i}-h_{a o, i}} \cdot 10, \quad k_{a, i}=\frac{L}{A} \frac{Q_{a, i}}{h_{a, i}-h_{a o, i}}
$$

ここに, $\eta_{a}:$ 空気の粘性係数 $(\mathrm{Pa} \cdot \mathrm{s})$

$h_{a o, i}:$ 図-5 の曲線関係(2)の $h_{a, i}$ の点での

接線と $h_{a}$ 軸との交点によって表さ れる空気圧力水頭 $(\mathrm{cm})$

ところで，毛管モデルの仮定に基づいて，間隙径 $d_{e}(\mathrm{~mm})$ は空気圧から次式によって算出される ${ }^{1)}$.

$$
d_{e, i}=\frac{4 \sigma}{\rho_{w} g h_{a, i}} \cdot 10^{4}
$$

一方，Bear によって紹介されている毛管モデルに関 する固有透過度を表す式に基づけば ${ }^{11}{ }^{1)}, h_{a, i}$ のとき 


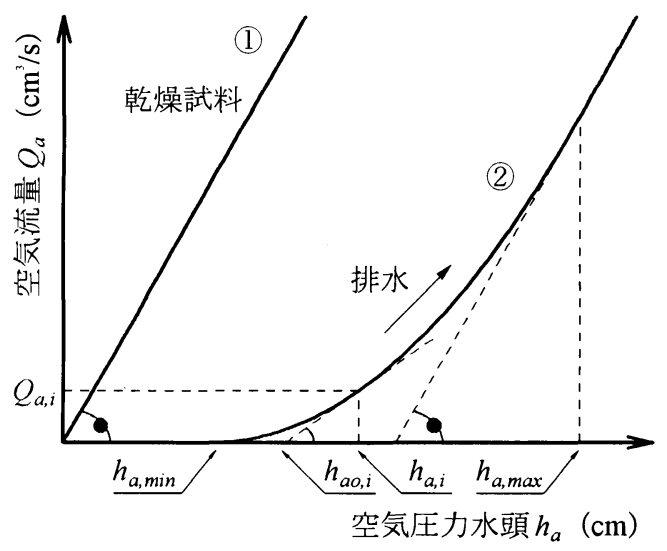

図一5（a） 空気圧力水頭と空気流量（概略）

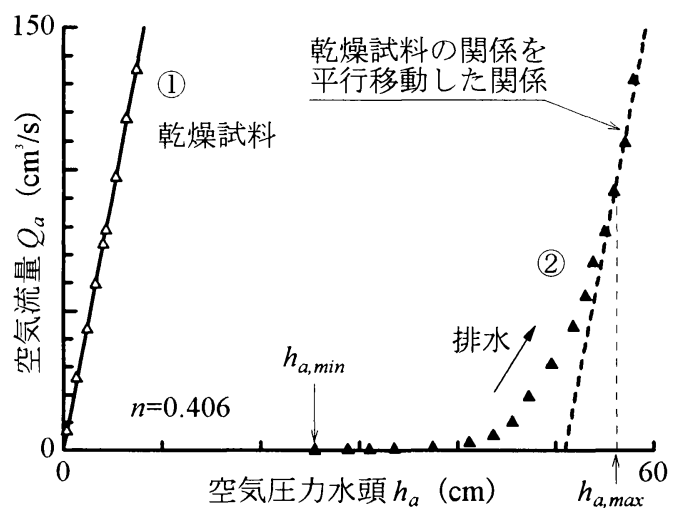

図-5(b) 空気圧力水頭と空気流量 (計測例 - 標準砂)

に空気圧によって間隙水が押し出され空気が流れた 間隙部分の間隙率 $n_{b, i}$ (累積間隙率と称す) は, 式(14) から算出する $k_{i}$ と式(15)加算出する $d_{e, i}$ をそれぞ れ用いて, 次式で算出される ${ }^{11}$.

$$
\begin{gathered}
\Delta n_{b, j}=\frac{32 \Delta k_{j}}{\left(d_{e, j} / 10\right)^{2}}, \Delta k_{j}=k_{j}-k_{j-1} \\
n_{b, i}=\sum_{j=1}^{i} \Delta n_{b, j}
\end{gathered}
$$

ここに, $\Delta n_{b, j}$ : 間隙径 $d_{e, j}$ の大きさを有する間隙 部分の間隙率

$\Delta k_{j}:$ 間隙径 $d_{e, j}$ の大きさを有する間隙部 分の固有透過度 $\left(\mathrm{cm}^{2}\right)$

この $n_{b, i}$ を用いて, 累積間隙体積百分率 $V_{b}(\%)$ を次 式により定義し算出する.

$$
V_{b, i}=\left(1-\frac{n_{b, i}}{n}\right) \cdot 10^{2}
$$

間隙径分布は, 式(15)から算出する $d_{e}$ と式(17)から 算出する $V_{b}$ の関係で表すことができる.

\section{(2) 計測結果}

図ー3 に示したように，圧入法による間隙径は， $U_{c}$ の増加に伴い分布範囲が広くなる傾向にあるもの の, 狭い範囲での分布頻度がかなり高く, 均等な分 布型を示す傾向にある．また，間隙径分布は，間隙 率の変化に伴い間隙径軸方向に平行移動する傾向に ある. 一方，圧入法の間隙径分布の代表径としての 平均間隙径 $d_{e}^{*}(\mathrm{~mm})$ を次式で定義して ${ }^{1)}$,

$$
d_{e}{ }^{*}=\frac{\sum \Delta n_{b, i}}{\sum\left(\Delta n_{b, i} / d_{e, i}\right)}
$$

$e$ と $d_{e}^{*}$ の $D_{w}$ に対する比の関係を調べた図一 4 によ れば, $d_{e}^{*} / D_{w}=0.2 \sim 0.35$ の大きさで, 水分法によ る $d_{m}^{*} / D_{w}$ より少し小さい.

\section{4. 圧入法と水分法による間隙径分布の対比}

図ー3によれば，圧入法による間隙径分布は，水 分法による分布と同じ範囲内にあるものの, 式 (15) の $h_{a, i}$ を図-5の $h_{a, \min }$ で代用して求まる最大径 $d_{e, \max }$ より大きな間隙径や $h_{a, i}$ を $h_{a, \max }$ で代用して求まる最 小径 $d_{e, \text { min }}$ より小さな径が計測され難いため分布範囲 は狭く, また，水分法によるものに較べて均等な分 布型となる。一方，図一6によれば，圧入法の平均 間隙径 $d_{e}{ }^{*}$ は水分法の平均間隙径 $d_{m}{ }^{*}$ の 9 割程度の大 きさになっているが，次の（1）で述べるように，両 者は同等のものと考えられる。

圧入法では飽和砂への空気圧入によって, 試料層 下端から上端に至る空気の流れる道が連続して形成 された間隙部分を毛管束で近似するのに対し，水分 法では間隙内に三次元的に形成される水一空気界面 構造を毛管束で近似するという原理的な違いが影響 していると考えられ，以下に考察する.

\section{(1) 間隙径 $d_{e}$ と $d_{m}$}

圧入法と水分法による間隙径 $d_{e}, d_{m}$ を求めるそれ ぞれの式(15) と式(4)を比較すると次のようである。

$$
\frac{d_{e}}{d_{m}}=\frac{h_{p}}{h_{a}}
$$

一般に, サクション $h_{p}$ は, $h_{p}=h_{a}-h_{w}\left(h_{w}\right.$ : 水の圧力 水頭 $(\mathrm{cm}))$ で表現されるため, 圧入法で空気を圧入 した時の試料層内の $h_{w}$ を $h_{w}=0$ とみなせば, $h_{p}=h_{a}$ となり, 式(19)より $d_{m}=d_{e}$ となる. しかしながら, 水分法での $h_{p}$ は試料層内の間隙水の存在状態が平衡 時のサクションであるのに対して，圧入法での $h_{a}$ は 間隙水を押し出し空気流が生じるときの空気圧で, $h_{p}$ とは異なる量であるので, 以下に調べる. 


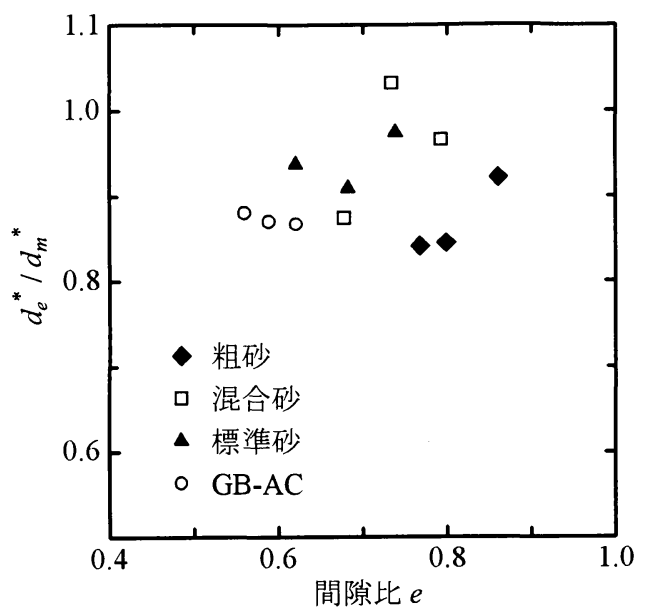

図一6 平均間隙径 $d_{e}^{*}$ と $d_{m}{ }^{*}$

圧入法では, ある空気圧 $h_{a, i}$ のときの含水量を計 測していないので， $\theta \sim h_{a}$ 関係と水分特性曲線とを 対比できないため, 圧入法の式(14)で得られる透気 係数と $h_{a}, h_{p}$ との対応で検討する.

図ー7は，図一2(c)，(d)に示した $\theta \sim h_{p}$ 関係を飽 和度 $S_{r} \sim h_{p}$ 関係で表現し直したもの(図中の実線, 破線はそれぞれ van Genuchten 式(10)による関係) と， 間隙水の存在が平衡状態とみなした湿潤土試料につ いての一次元透気試験により得られた $S_{r}$ と比透気係 数 $k_{a t} / k_{a d}\left(k_{a t}\right.$ : 湿潤土の透気係数 $(\mathrm{cm} / \mathrm{s}), k_{a d}$ : 炉乾燥 土の透気係数 $(\mathrm{cm} / \mathrm{s}))$ の関係 $\left.{ }^{12)}, 13\right)$ ，を対比して示 したものである.そして，ある $S_{r}$ に対応する $h_{p}, k_{a t} / k_{a d}$ をそれぞれ読み取り,$k_{a t} / k_{a d} \sim h_{p}$ 関係を調べたのが 図ー8である(但し，いずれの試料についても $S_{r} \sim h_{p}$ 関係の間隙率 $n$ と $S_{r} \sim k_{a t} / k_{a d}$ 関係の $n$ は若干異なる). 一方，圧入法において，式(14)の透気係数 $k_{a, i}$ は, ある飽和度に対応して得られる值であるため, $k_{a t} / k_{a d}$ $=k_{a, i} / k_{a d}$ として, $k_{a t} / k_{a d} \sim h_{a, i}$ 関係を図一8に重ね合わ せて示した. $k_{a t} / k_{a d} \sim h_{p}$ 関係と $k_{a t} / k_{a d} \sim h_{a, i}$ 関係はほ ぼ同一の関係になり, $h_{a} \fallingdotseq h_{p}$ である. 従って, 式(19) より $d_{e} \fallingdotseq d_{m}$ であり，毛管径として同型の式で定義す る両手法の間隙径は同程度のものと評価される. 即 ち, 図一6 の平均間隙径 $d_{e}{ }^{*}$ と $d_{m}{ }^{*}$ のずれは, $d_{e}{ }^{*}, d_{m}{ }^{*}$ をそれぞれ算出するのに用いる間隙体積を表す要因 $\left(\triangle n_{b}\right.$ と $\left.f\left(d_{m}\right)\right)$ や表現される分布の範囲の違いによ るものである.

\section{(2) 両手法による分布の相違}

$h_{a} \fallingdotseq h_{p}$ であるので, 図-5 の $h_{a, \min }, h_{a, \max }$ の值を $h_{p}$ の值に置換し，図一2 からその $h_{p}$ に対応する $\theta$ を求 め更に $S_{r}$ に換算して, 各々の試料, 間隙率での $h_{a, m i n}$, $h_{a, \max }$ に対応する含水量を推定すると, いずれについ



図-7 飽和度とサクション $h_{p}$, 比透気係数の関係



図ー8 サクション $h_{p}$ と式(14)の空気圧力水頭 $h_{a, i}$

ても $h_{a, \min }$ のとき $S_{r}=90 \%$ 程度, $h_{a, \max }$ のとき $S_{r}=20 \%$ 程度である。このことから，圧入法では， $h_{a, \text { min }} よ り$ 小さな空気圧のとき飽和試料層を通過する空気流が 生じないが空気は侵入していること， $h_{a, \max }$ より大き な空気圧のとき微細な間隙部分や空気流に垂直な方 向の間隙部分の間隙水が押し出されず，そのような 間隙部分が空気流に寄与し難いことが考えられる.

この結果，圧入法で評価する間隙体積は形成され た空気道の部分に相当し，水分法の同じ間隙径に対 する間隙体積は間隙の三次元的空間からの排水量に 相当し，これが，図ー3 の両手法による間隙径分布 のずれとして，圧入法による分布の範囲が水分法に よるものより狭くなり，累積間隙体積百分率として 
の圧入法の $V_{b}$ が水分法の $V_{r}$ よりも大きくなる原因 と考えられる．また，圧入法による分布計測值の妥 当性注毛管模型によって確認しているので ${ }^{1)}$ ，圧入 法からの水分法による分布のずれは，毛管モデルか らのずれとして「間隙が瘤状に広くなったり狭くな ったり」する結果によると判断できよう。このこと は，間隙構造の表現に指針を与えるものであり，い ずれの間隙径分布が良いかという観点ではなく，そ の特徵に合わせて分布を活用することが期待される。

\section{（3）両手法の間隙径分布の関係付け}

Wittmann $^{14)}$, Kenney らは ${ }^{15)}$ ，フィルタ層は, 図ー9 のように, 間隙径 $d_{p}(\mathrm{~mm}) \sim p(\%)(p:$ ある間 隙径より小さい径を有する間隙部分の全間隙に対す る割合) 関係で表される間隙径分布を有する微小厚 さの多孔板が $m^{*}$ 枚から成るとする仮定で，ある間 隙径に等しい粒径 $D_{p}(\mathrm{~mm})$ を有する土粒子がフィル 夕層を通過しない確率 $P^{\prime}(\%)$ を次式で与えた。

$$
P^{\prime}=\left\{1-(1-p / 10)^{m^{*}}\right\} \cdot 10^{2}, \quad m^{*}=L_{F} / D_{F}
$$

\section{ここに, $L_{F}$ : フィルタ層厚さ $(\mathrm{mm})$}

\section{$D_{F}:$ フィルタ材の代表粒径 $(\mathrm{mm})$}

これは，間隙が瘤状に広くなったり狭くなったりす るために，粒子通過は小さめの間隙径に依存し，ま た，フィルタ層が厚いほど，指数 $m^{*}$ が大きくなり， 大きめの粒子が通過し難くなることを表現したもの である．即ち，式(20)により，大きい瘤がある多孔 板の間隙径分布 $d_{p} \sim p$ を粒子通過に支配的な小さめ の瘤の間隙径分布 $d_{p} \sim P^{\prime}$ に表現し直すことができる.

上記の「粒子通過」を圧入法の「空気通過」に置 き換えて，式(20)の $p$ を水分法の $V_{r}, P^{\prime}$ を圧入法の $V_{b}$ とみなして，「大きい瘤がある間隙径分布を示す 水分法による分布」から「毛管で表現した圧入法に よる分布」に修正を試みた例を図ー10 に示す，い ずれも $m^{*}=3$ のときが比較的合致しているが，混合 砂は分布型がずれて現れ，均等な標準砂の方が良く 表現されているようにみえる。一方, $m^{*}$ 值は, 式(20) の $L_{F}$ を圧入法の試料高さ $L, D_{F}$ を平均粒径 $D_{w}$ とす ると, 混合砂で $m^{*}=30 / 0.256 \fallingdotseq 117$, 標準砂で $m^{*} \fallingdotseq$ 160 となり，フィッティングされたときの $m^{*}$ に較心゙ てかなり大きい，圧入法で生じる空気流は大きい間 隙径部分を探索するべく曲がることができるので， 多孔板 1 枚の厚さを $D_{F}$ よりも厚くする方が修正対 応が良くなり，結果的に $m^{*}$ 值が小さく評価される と考えられる. Childs らが水分法による間隙径分布 から透水係数を表現するために ${ }^{4)} ， 2$ 枚の多孔板の 結びつきを考えた理由もここにあるかも知れない．

水分法による分布は, 式(20)に基づく修正により,

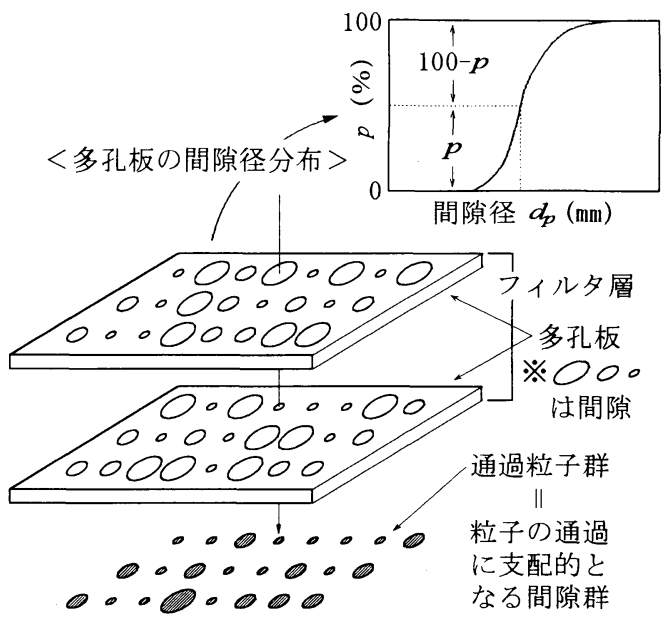

図－9 フィルタ層の粒子通過の概念 ${ }^{14), 15}$

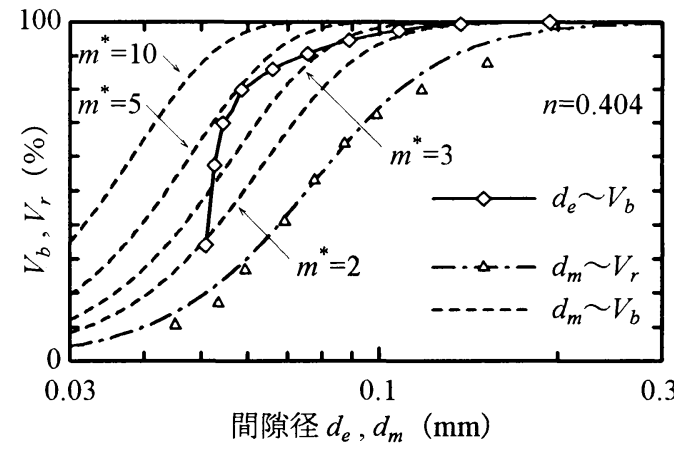

図一10 (a) 水分法による間隙径分布の修正 (混合砂)

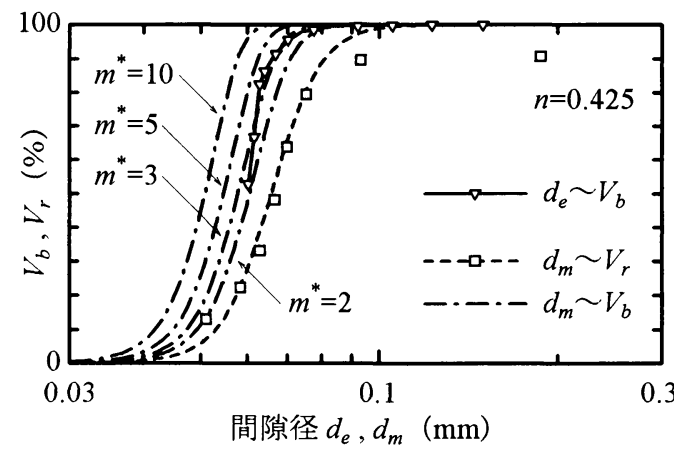

図一10(b) 水分法による間隙径分布の修正 (標準砂)

大きめの間隙径部分が現れ難くなり，更にその部分 が小さめの間隙径部分の体積評価に含まれ，そして， 圧入法による均等な分布に近づく. 即ち, 三次元的 空間からの排水にかかわる閒隙部分を表現する水分 法と空気通過のみにかかわる部分を毛管表現する圧 入法による間隙径分布の関係は，間隙体積評価の違 いとすることで解釈される。 


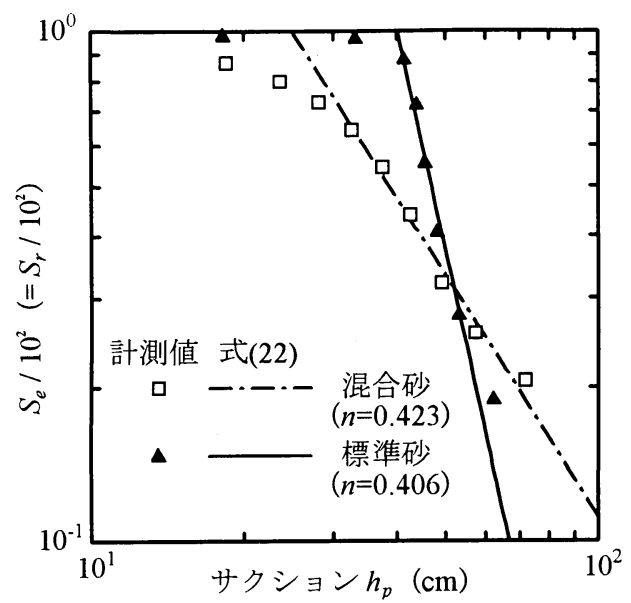

図-11 空気侵入値 $h_{b}$, パラメータ入の算出の例

\section{（4）空気侵入值と圧入法での空気通過最小圧}

圧入法において，飽和試料層を空気が流れ始める ときの空気通過最小圧 $h_{a, \text { min }}$ の意味を Air Entry Value (AEV と略称) と同意味に使用されている空気侵入 值との関連で若干考察したい.

Brooks らによる水分特性曲線の推定式は ${ }^{7)}$,

$$
S_{e}\left(=\frac{\theta-\theta_{r}}{\theta_{s}-\theta_{r}} \cdot 10^{2}\right)=\left(\frac{h_{b}}{h_{p}}\right)^{\lambda} \cdot 10^{2}, h_{b} \geqq h_{p}
$$

ここに, $h_{b}:$ 空気侵入值 $(\mathrm{cm})$

$\lambda:$ 土の種類で決まるパラメータ (Brooks

らは間隙径分布指数 (Pore Size

Distribution Index) と称している)

であり，この式の両辺を $10^{2}$ で除して，更に，両辺 の対数をとると次式となる.

$$
\log \left(S_{e} / 10^{2}\right)=\lambda\left(\log h_{b}-\log h_{p}\right)
$$

図ー11のように, $\log h_{p} \sim \log \left(S_{e} / 10^{2}\right)$ 関係を直線で近 似し, その直線上の $S_{e} / 10^{2}=1$ のときのサクション から $h_{b}$ が，直線の傾きから入がそれぞれ求まる，表 -2 には, 式(21)の $\theta_{r}=0, \theta_{s}=n$ と仮定して, 図一 2 のそれぞれの水分特性曲線に対して図-11の整理 で求めた $h_{b}, \lambda$ をそれぞれ示した. 図一3 や表一2 によれば, $h_{b}$ は $D_{w}$ が小さくなるに伴い大きくなり，

入は水分法の間隙径分布が緩やかとなるに伴い小さ くなる傾向にそれぞれある7.

図ー12 は，表一2の $h_{b}$ に対して各々の試料，間隙 率について圧入法で計測された $h_{a, \min }$ の関係を示し たもので, 圧入法で決定し難い $h_{a, \text { min }}$ は $h_{b}$ の 6 割程 度の大きさであることが認められる.
表－2 式(21)における空気侵入值 $h_{b}$, パラメータ $\lambda$

\begin{tabular}{|c||c|c|c|c|}
\hline 試料名称 & 間隙率 $n$ & 過程 & $h_{b}(\mathrm{~cm})$ & $\lambda$ \\
\hline \hline 粗砂 & 0.434 & 排水 & 14.2 & 5.075 \\
& 0.444 & 排水 & 13.1 & 3.761 \\
& 0.463 & 排水 & 13.1 & 4.978 \\
\hline 混合砂 & 0.404 & 排水 & 31.0 & 2.844 \\
& 0.423 & 排水 & 24.9 & 1.576 \\
& 0.442 & 排水 & 24.8 & 1.727 \\
\hline 標準砂 & 0.383 & 排水 & 44.8 & 5.178 \\
& 0.406 & 排水 & 40.3 & 4.540 \\
& 0.425 & 排水 & 38.2 & 4.701 \\
\hline GB-AC & 0.359 & 排水 & 38.9 & 7.609 \\
& 0.371 & 排水 & 35.4 & 5.226 \\
& 0.383 & 排水 & 34.9 & 5.557 \\
\hline
\end{tabular}

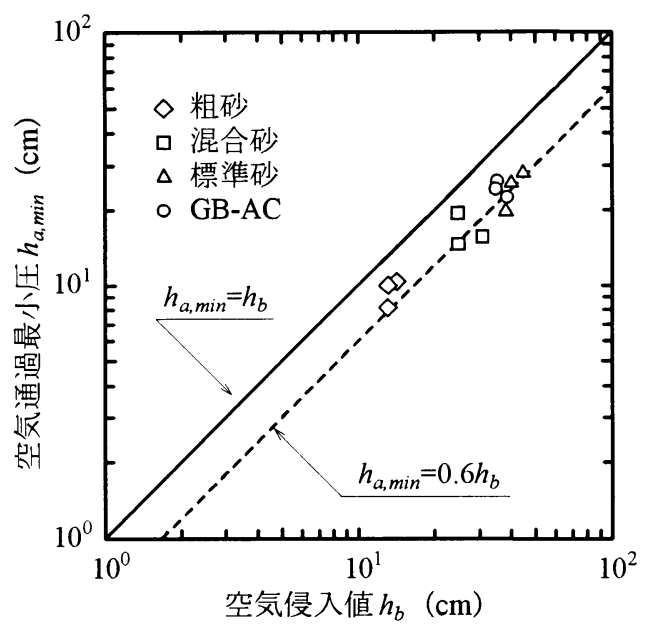

図-12 空気侵入值 $h_{b}$ と空気通過最小圧 $h_{a, m i n}$

\section{5. おわりに}

本論文は，間隙径分布を計測するために提案した 圧入法に対して，水分特性曲線による水分法を用い て得られる砂の間隙径分布を対比するとともに，圧 入法の間隙径分布や両手法の分布の関係について考 察した. その結果, 以下の事項が判明した.

（1）水分法による間隙径分布は水分特性曲線を $90^{\circ}$ 左回転した形状になり，それは粒度分布を平行移動 したような分布型となる，それに対し，圧入法によ るものは，粒度に関係なく分布範囲が狭く均等な分 布型となる傾向にある．また，圧入法の平均間隙径 $d_{e}{ }^{*}$ は, 水分法の平均径 $d_{m}{ }^{*}$ の約 9 割の大きさである.

（2）圧入法における飽和試料一の圧入空気圧 $h_{a}$ は水 分法におけるサクション $h_{p}$ に相当する. また, $h_{a} \sim$ 比透気係数 $k_{a t} / k_{a d}$ 関係と $h_{p} \sim k_{a t} / k_{a d}$ 関係が同一の関 係となり，圧入法による間隙径 $d_{e}$ と水分法による間 隙径 $d_{m}$ は同じものと評価される. その結果, 上記 (1) の $d_{e}{ }^{*}$ と $d_{m}{ }^{*}$ の差は, 平均径の算出に関係する次の (3) に述べる累積間隙体積百分率の差による影響である. 
（3）圧入法と水分法による間隙径分布のずれは，間 隙体積を表現する累積間隙体積百分率としての圧入 法の $V_{b}$ が毛管形状の空気道の間隙部分に相当する のに対し, 水分法の $V_{r}$ が瘤状に広くなったり狭くな ったりする間隙の三次元的空間からの排水量に相当 するという違いによるものである。そのため, Wittmann 等によって示されたフィルタ層の粒子通過 の確率モデルに基づいて瘤状の間隙の影響を表現す るため, 水分法の累積間隙体積百分率 $V_{r}$ を修正した ところ, その修正 $V_{r}$ は圧入法の累積間隙体積百分率 $V_{b}$ と比較的合致する.

（4）圧入法の飽和試料中に空気流が生じ始めるとき の空気通過最小圧力 $h_{a, \text { min }}$ は, 水分特性曲線から得 られる空気侵入值とか AEV に相当する $h_{b}$ の 6 割程 度の大きさである.

本研究は平成 7 年度, 平成 8 年度の文部省科学研 究費補助金 (基盤研究 (B) (2), 課題番号 : 07455189, 研究代表者: 宇野尚雄) の補助を受けた。関係各位 に謝意を表する.

\section{参考文献}

1）神谷浩二, 宇野尚雄, 松島健之：「空気圧入法」によ る砂質土の間隙径分布の計測, 土木学会論文集, No. 541/III-35, pp. 189-198, 1996.

2) Morel-Seytoux, H. J. : Introduction to Flow of Immiscible Liquids in Porous Media, Flow through Porous Media (edited by De Wiest, R. J. M.), Academic Press, Inc., pp.455-516, 1969.

3）土壌物理研究会編: 土の物理学一土質工学の基礎一, 森北出版, pp. 199-238, 1979.

4) Childs, E. C. and Collis-George, N. : The Permeability of Porous Materials, Proceedings of the Royal Society of London, Ser.A, Vol.201, pp.392-405, 1950.
5) Baver, L. D. : Soil Physics, 3rd ed., John Wiley \& Sons, Inc., pp.270-272, 1956.

6) Marshall, T. J. : A Relation between Permeability and Size Distribution of Pores, The Journal of Soil Science, Vol.9, No.1, pp.1-8, 1958.

7) Brooks, R. H. and Corey, A. T. : Properties of Porous Media Affecting Fluid Flow, Journal of the Irrigation and Drainage Division, Proceedings of the American Society of Civil Engineers, Vol.92, No.IR2, pp.61-88, 1966.

8）宇野尚雄, 佐藤 健, 柘植浩史 : $2 、 3$ の砂質土の 水分保持特性, 不飽和土の工学的性質研究の現状シ ンポジウム発表論文集, pp. 187-192， 1987.

9) van Genuchten, M. Th. : A Closed-form Equation for Predicting the Hydraulic Conductivity of Unsaturated Soils, Soil Science Society of America Journal, Vol.44, pp.892898, 1980.

10) 土質工学会編 : 土質工学ハンドブック, 土質工学会, p. 69, 1982.

11) Bear, J. : Dynamics of Fluids in Porous Media, American Elsevier Publishing Company, Inc., pp.161-164, 1972.

12）宇野尚雄, 杉井俊夫, 神谷浩二: 比表面積測定に基 づく土粒子物性と透気性・透水性の考察, 土木学会 論文集, No. 469/III-23，pp. 25-34， 1993.

13）宇野尚雄, 神谷浩二, 鬼頭明義, 杉井俊夫 : 湿潤土 の透気係数について, 第 5 回地盤工学シンポジウム 論文集 (土質工学会中部支部), pp. 77-82，1993.

14) Wittmann, L. : The Process of Soil-Filtration-Its Physics in Engineering Practice, Proceedings of the 7th European Conference on Soil Mechanics and Foundation Engineering, Vol.1, pp.303-310, 1979.

15) Kenney, T. C., Chahal, R., Chiu, E., Ofoegbu, G. I., Omange, G. N. and Ume, C. A. : Controlling Constriction Sizes of Granular Filters, Canadian Geotechnical Joumal, Vol.22, pp.32-43, 1985.

(1997. 7.18 受付)

\title{
THE DISTRIBUTION OF SAND VOID DIAMETER BY AIR INTRUSION METHOD AND MOISTURE CHARACTERISTIC CURVE METHOD
}

\author{
Takao UNO, Kohji KAMIYA and Kohji TANAKA
}

The air intrusion method based on the capillary model was produced to measure the distribution of soil void diameter. In the present paper, the void diameter distribution measured by air intrusion method is compared with the one estimated from moisture characteristic curve. As a result, it is shown that the shape and range of void diameter distributions by air intrusion method become more uniform and more narrow than the distributions by moisture characteristic curve, respectively, and that the mean void diameters by air intrusion method correspond to $90 \%$ of that by moisture characteristic, with consideration of the connecting relationship between both curves, and so on. 